\title{
Plastic responses in the coral Pocillopora acuta to extreme low-light conditions with and without food provision
}

\author{
Jenny Fong ${ }^{1}\left[\right.$ [ $\cdot$ Rosa Celia Poquita-Du' ${ }^{1}$ Peter A. $\operatorname{Todd}^{1}[\mathbb{C}$
}

Received: 27 February 2021 / Accepted: 1 May 2021 / Published online: 19 June 2021

(c) The Author(s) 2021

\begin{abstract}
This study examines phenotypically plastic responses in Pocillopora acuta collected from a highly urbanized reef environment to extreme low-light conditions. While among-species differences in how corals cope with low light are well documented, much less is known about within-species responses. It also remains unclear how extreme low light and provision of food may interact and influence coral physiology. Clonal fragments from six colonies (genotypes) of $P$. acuta were subjected to two light treatments with mean midday irradiances of 4 and $40 \mu \mathrm{mol}$ photons $\mathrm{m}^{-2} \mathrm{~s}^{-1}$ photosynthetically active radiation (PAR), representing just 0.5 and 5\% ambient light level, and were either fed with zooplankton or not fed for nine days. Corals maintained in 4 PAR had lower endosymbiont density but higher cellular chlorophyll $a$ concentration than those in 40 PAR. Feeding rates were similar in both light treatments and had no significant effects on endosymbiont density and chlorophyll $a$ concentrations. While genotypes varied in the level of phenotypic plasticity expressed for both photoacclimation and heterotrophy, most displayed similar directions in their responses, indicating photoacclimation in $P$. acuta is broadly predictable. Our study demonstrates that $P$. acuta from Singapore is able to acclimate to very low-light conditions by adjusting their photophysiology, providing additional evidence that this species is resilient to urbanization-related stress.
\end{abstract}

\section{Introduction}

Light availability is arguably the most important factor determining the growth and productivity of scleractinian corals (Roth 2014). However, coral communities in urban reefs are frequently exposed to high levels of sediment and turbidity, resulting in low-light availability (Heery et al. 2018). Corals have developed a number of strategies to survive in low-light environments such as increases in endosymbiont densities and chlorophyll concentrations to enhance their light capturing abilities (Falkowski and Dubinsky 1981; Titlyanov and Titlyanova 2002). Some corals can also upregulate their heterotrophy to compensate for the

Responsible Editor: C. Wild.

Reviewers: N. Browne and anundisclosed expert.

Peter A. Todd

dbspat@nus.edu.sg

Jenny Fong

jenny.jenny@u.nus.edu

1 Experimental Marine Ecology Laboratory, National University of Singapore, Singapore 117558, Singapore decline in their photosynthetic activity (Houlbrèque and Ferrier-Pagès 2009). While among-species differences in how corals cope with low light are well documented, much less is known about within-species responses (Todd 2008).

Intraspecific variation in the phenotypes expressed by corals can occur as a consequence of genetic differences, phenotypic plasticity, or both (Foster 1979; Schlichting 1989). Phenotypic plasticity represents environmentalinduced changes in the morphology, physiology, behaviour, and various life-history traits of an individual, enabling it to produce, within the constraint of its genotype, phenotypes that fit the environment it inhabits (Bradshaw 1965; Stearns 1989). The degree of plasticity exhibited across a range of environmental conditions is likely to vary among genotypes (i.e., genotype $\times$ environment $(\mathrm{G} \times \mathrm{E})$ interaction; Stearns 1989; Pigliucci 2005), and this variation can be acted on by natural selection (Bradshaw 1965; Schlichting and Pigliucci 1998).

Changes in light level have been shown to cause corals to alter their morphology, physiology, and behaviour-a type of phenotypic plasticity known as photoacclimation (Titlyanov and Titlyanova 2002; Todd et al. 2004). For instance, Titlyanov et al. (2001a) determined that Stylophora pistillata fragments increased their endosymbiont densities and 
cellular chlorophyll concentrations when the fragments were transplanted from high-light level (95\% incident light level, $\mathrm{I}_{0}$ ) to low-light level (30\% $\left.\mathrm{I}_{0}\right)$. Falkowski and Dubinsky (1981) showed that $S$. pistillata fragments that were kept in shaded environment $\left(0.3-1 \% \mathrm{I}_{0}\right)$ had threefold cellular chlorophyll concentrations compared to fragments kept in high-light environment (50-90\% $\mathrm{I}_{0}$ ). These photoacclimation strategies are, however, not consistent among studies (e.g., McCloskey and Muscatine 1984; Titlyanov et al. 2000), probably due to the differences in the light regimes, acclimation duration, and coral species examined (Titlyanov and Titlyanova 2002). Several studies have demonstrated that coral colonies can fail to photoacclimate and experience high mortality when they are transplanted from their natal location to the opposite end of their light distribution range (Dustan 1982; Iglesias-Prieto et al. 2004; Bongaerts et al. 2011).

Corals might adjust their feeding rates in response to variation in light levels to maintain a positive energy balance (Houlbrèque and Ferrier-Pagès 2009). For instance, Anthony and Fabricius (2000) reported that Goniastrea retiformis doubled its feeding rates and maintained its growth despite 35-47\% decline in photosynthesis due to prolonged shading. Similarly, Anthony (2000) found that Pocillopora damicornis and Acropora millepora collected from turbid inshore reefs had enhanced heterotrophic intakes compared to their conspecifics collected from less turbid nearshore and offshore reefs in the Great Barrier Reef, Australia. However, heterotrophic feeding can cause negative impacts on reproduction in P. verrucosa (Séré et al. 2010). Similar light and dark feeding rates have also been described in corals (e.g., Lewis 1976; Lavorano et al. 2008), indicating that not all possess the ability to shift from being phototrophs to heterotrophs.

Coral communities in urban reefs are frequently exposed to low-light availability due to high levels of sedimentation and turbidity as a result of anthropogenic stressors including coastal construction and dredging operations (Heery et al. 2018). On reefs near to dredging activities $(<2 \mathrm{~km})$, daily light integral (DLI) can drop below 0.1 mol photons $\mathrm{m}^{-2} \mathrm{~d}^{-1}$ for days to weeks (Jones et al. 2015). Only a few studies have investigated the effects of such extreme low light on corals (e.g., Titlyanov and Titlyanova 2002; Bessell-Browne et al. 2017) and they did not explicitly test for phenotypic plasticity. To better understand plastic responses in corals to extreme low-light levels, we asked: (1) how does Pocillopora acuta respond to low-light conditions with or without food provision, and (2) how do responses vary among genotypes?

\section{Materials and methods}

\section{Study species and sampling sites}

Singapore is a densely populated city state located just north of the equator. Sediment pollution is a major issue (Chou 2006; Todd et al. 2010); for example, while late-morning light levels range from $\sim 5$ to $\sim 500$ PAR in shallow depths (1-3 m), under especially turbid conditions these can drop to below $0.5 \%$ surface ambient for several days (Browne et al. 2015; Chow et al. 2019).

Pocillopora acuta Lamarck 1816 is commonly found on the shallow reefs $(0-3 \mathrm{~m})$ to the south of the main island of Singapore (Poquita-Du et al. 2019b). This species represents the last Pocilloporidae remaining in Singapore (previously there were five species) and is hence considered relatively resilient to local conditions (Poquita-Du et al. 2019a, b). A total of six colonies, at least $10 \mathrm{~m}$ apart and $>15 \mathrm{~cm}$ in diameter, were collected at approximately $3 \mathrm{~m}$ depth from fringing reefs at Pulau Satumu ( $\left.1^{\circ} 09^{\prime} 39^{\prime \prime} \mathrm{N}, 103^{\circ} 44^{\prime} 26^{\prime \prime} \mathrm{E}\right)$ and Kusu Island ( $1^{\circ} 13^{\prime} 25^{\prime \prime} \mathrm{N}, 103^{\circ} 51^{\prime} 38^{\prime \prime}$ E), i.e., three colonies from each site. Molecular studies by Pang et al. (2021) revealed that $P$. acuta colonies at least $10 \mathrm{~m}$ apart on Singapore's reefs were genetically distinct. While Pulau Satumu is located farther away from the mainland Singapore compared to Kusu Island, and could be expected to be less affected by urbanization, both reefs have similar sedimentation rates ( $\mathrm{Ng}$ et al. 2019). After collection, colonies were maintained in the flow-through outdoor aquaria at the St John's Island National Marine Laboratory. Each colony was subsequently divided into 16 fragments $(3.8 \pm 0.5 \mathrm{~cm}$ height, mean $\pm \mathrm{SD}$ ) and these were kept in a holding tank for 1 week of acclimation under $50 \%$ shade netting (midday irradiance ranged between $\sim 100$ and $\sim 300$ PAR).

\section{Experimental design}

To examine the responses of corals to acute periods of very low light, coral fragments from each genotype were assigned randomly to two light regimes: (1) low light ( 95\% shading, average midday irradiance, i.e. between 10.30 and 13.30, of $40 \mu \mathrm{mol}$ photons $\mathrm{m}^{-2} \mathrm{~s}^{-1}$ photosynthetically active radiation (PAR) and mean daily light integral, DLI, of 1) and, (2) very low light $(\sim 99.5 \%$ shading, average midday irradiance 4 PAR and mean DLI of 0.1; Fig. S1). As such lowlight levels tend to be transient in Singapore (Browne et al. 2015), the experiment ran for 9 days only. Further, multiple studies have shown that corals can acclimate to their new environment within days (Titlyanov and Titlyanova 2002; Titlyanov et al. 2001b; Poquita-Du et al. 2019a). A PAR sensor (LI-COR LI-192) was used at the start of the experiment to determine the shading levels. For each light level, corals 
were either fed daily with freshly hatched Artemia nauplii $1^{-1}$ (the target was 5000 Artemia nauplii $1^{-1}$ each day, but the exact number was determined by counting nine replicate samples under a stereomicroscope) for $2 \mathrm{~h}$, or starved. Each treatment combination was replicated using four coral fragments $(N=96: 2 \times$ light, $2 \times$ food, $6 \times$ genotype, $4 \times$ replicate). Every coral fragment was placed into an individual $1 \mathrm{~L}$ tank supplied with fresh filtered seawater and aeration. The tanks were placed in a water bath to maintain a uniform temperature and were shuffled every three days to avoid any positional effects. Daily light levels and water temperature were monitored continuously using HOBO data loggers (Onset UA-002-08). A calibration constant of 0.0185 was applied to convert the lux readings recorded by the HOBO loggers into PAR (Thimijan and Heins 1983). Very little variation in temperature was recorded throughout the experiment $\left(29.69 \pm 0.22^{\circ} \mathrm{C}\right.$; mean $\left.\pm \mathrm{SD}\right)$.

Prey clearance rates were determined on day 1, 3, 5, 7, and 9. At the end of the 2-h feeding session, any remaining Artemia inside the tanks were filtered by pouring all the water inside the tanks over a $50 \mu \mathrm{m}$ fine-mesh filter before being concentrated into $10 \mathrm{~mL}$ samples. Three $1 \mathrm{~mL}$ subsamples were counted under a stereomicroscope to determine the number of prey ingested, which was then normalized to surface area (using the paraffin wax technique; Stimson and Kinzie III 1991) to obtain prey clearance rates. Initial analyses revealed that prey clearance rates did not vary among days, so data were pooled and averaged.

\section{Endosymbiont density and chlorophyll (chl) $a$ concentrations}

At the end of the experiment, endosymbionts were isolated using the Waterpik technique (Johannes and Wiebe 1970). The resultant slurry was filtered, centrifuged, resuspended in $5 \mathrm{~mL}$ filtered seawater, and subsequently stored at $-20^{\circ} \mathrm{C}$. A $1 \mathrm{~mL}$ aliquot was taken out for enumeration of endosymbiont cells using a Neubauer Improved Haemocytometer under a compound light microscope with at least eight subsamples. The endosymbiont density was normalized to coral surface area.

Chlorophyll (chl) $a$ was extracted from the endosymbionts using $100 \%$ acetone for $24 \mathrm{~h}$ at $4{ }^{\circ} \mathrm{C}$. Pigment absorbance readings were taken at 630,663 , and $750 \mathrm{~nm}$ using a spectrophotometer (Shimadzu UVmini-1240). Chl $a$ content was then calculated using equations from Jeffrey and Humphrey (1975) and normalized to (1) endosymbiont density to obtain cellular chl $a$ concentration, and (2) surface area to obtain areal chl $a$ concentration.

\section{Statistical analyses}

Eight fragments had died by the end of the experiment and were hence excluded from the analyses (Table S1). Using R statistical software (R v. 3.6.2, R Core Team 2019), two-way analysis of variance (ANOVA) was performed to quantify the effects of light and genotype on prey clearance rates, and three-way ANOVA to determine the effects of light, feeding, and genotype on endosymbiont density and chl $a$ concentrations. Prey clearance rates were square-root-transformed to meet the normality assumption. Post hoc Tukey's honest significant different (HSD) tests were performed for all pairwise comparisons. Reaction norms were plotted to visualize any $\mathrm{G} \times \mathrm{E}$ interactions (Stearns 1992).

\section{Results and discussion}

It is well recognized that corals respond to changes in their light environment, but it remains unclear how extreme low light and provision of food may interact and influence coral physiology. Further, among-genotype variation for photoacclimation and heterotrophy is not well documented. The present study examined photoacclimation and heterotrophic intake in response to two low-light levels among coral fragments from six genotypes of $P$. acuta collected from Singapore's turbid urban reefs. Results indicate that the differences in endosymbiont density and chl $a$ concentrations were influenced mainly by light, not food availability. We also found that the degree of plastic responses varied significantly among genotypes, with reaction norms crossed for all the measured variables suggesting genetic variation for plasticity.

Light regime had a significant effect on endosymbiont density [ANOVA, $F(1,64)=27.90, P<0.001]$ and cellular chl $a$ concentrations [ANOVA, $F(1,64)=19.69, P<0.001$; Table S2]. Coral fragments maintained in 4 PAR had significantly lower endosymbiont densities but significantly higher cellular chl $a$ concentrations compared to those in 40 PAR (Fig. 1). The reduction in endosymbiont density was most likely a consequence of reduced cell growth and division as, at 4 PAR, photosynthesis is likely limited (Kleypas et al. 1999). Having lower densities might also minimize self-shading among endosymbionts, optimizing their light capturing capacity (McCloskey and Muscatine 1984). Corals are known to photoacclimate to low light by increasing their cellular chlorophyll concentrations, resulting in greater light capture potential of each endosymbiont (Falkowski and Dubinsky 1981; Titlyanov and Titlyanova 2002).

Coral fragments at 4 PAR maintained similar pigmentation $\mathrm{cm}^{-2}$ as fragments at 40 PAR across all genotypes (Fig. 1). In a longer running experiment, Bessell-Browne et al. (2017) found that P. acuta and Acropora millepora 
Fig. 1 Reaction norms for endosymbiont density, cellular chl $a$ concentration, areal chl $a$ concentration, and prey clearance rates. PAR photosynthetically active radiation. Vertical bars $=$ standard error
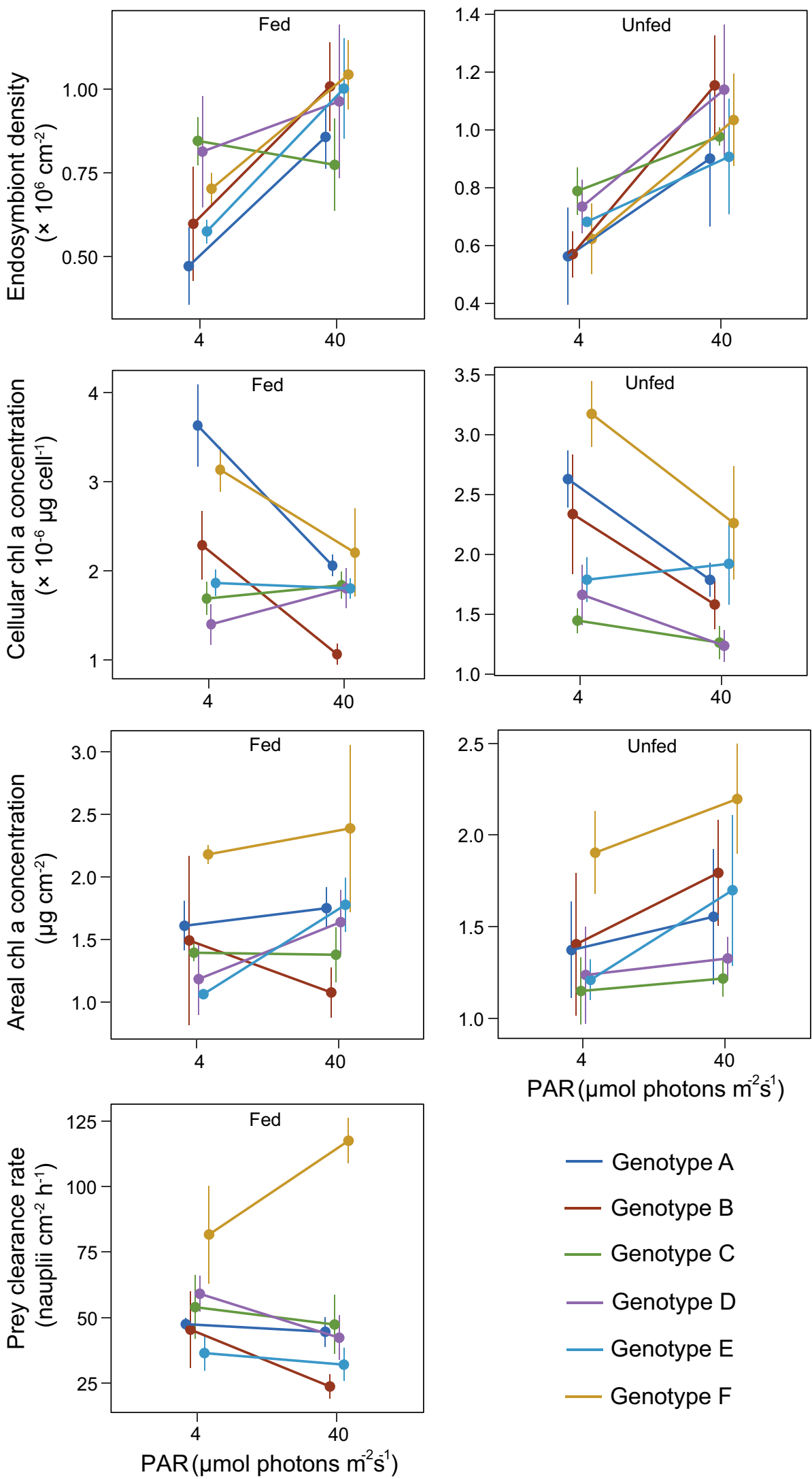
collected from mid-shelf reefs in the Great Barrier Reef gradually lost their pigmentation after 10 day of exposure to $<0.1$ DLI and became skeleton white after 20 days, consistent with patterns reported in past studies that exposed corals to complete darkness (Yonge and Nicholls 1931; Hoegh-Guldberg and Smith 1989; Titlyanov, et al. 2001a). The high tolerance of $P$. acuta in this study to 9 days of very low light could be due to the presence of resilient genotypes, of either the coral hosts or their endosymbionts, that are adapted to the local turbid conditions. Nevertheless, it is also possible that a longer duration of low-light environment may cause pigment loss.

Pocillopora acuta coral fragments consumed an average of $51.30 \pm 28.62( \pm \mathrm{SD})$ Artemia nauplii $\mathrm{cm}^{-2} \mathrm{~h}^{-1}$, but these quantities did not differ significantly between the two low-light regimes [ANOVA, $F(1,32)=0.68, \mathrm{P}=0.415$; Table S3], similar to findings by Clayton and Lasker (1982) and Lavorano et al. (2008), who also found no difference in the diurnal and nocturnal feeding rates of Pocillopora damicornis. Clayton and Lasker (1982) reported that $P$. damicornis fragments that were maintained under daylight conditions in aquaria were able to ingest 0.4 Artemia nauplii polyp $\mathrm{p}^{-1}$ in $15 \mathrm{~min}$, or approximately 53 nauplii $\mathrm{cm}^{-2} \mathrm{~h}^{-1}$ assuming the average number of polyps in $P$. damicornis is $33.4 \mathrm{~cm}^{-2}$ (Palardy et al. 2006), when they were presented with $0.9 \mathrm{~mL}$ of Artemia nauplii $\mathrm{L}^{-1}$. This suggests that the feeding rates observed in the current study did not represent upregulation as they were comparable to the diurnal rates reported in Clayton and Lasker (1982). We also found no significant effects of feeding on endosymbiont density [ANOVA, $F(1,64)=0.30, P=0.587$ ] and chl $a$ concentrations [cellular: ANOVA, $F(1,64)=1.76, P=0.189$; areal: ANOVA, $F(1,64)=0.43, P=0.514$; Table S2]. These results are in contrast with findings from Ferrier-Pagès et al. (2003) and Houlbrèque et al. (2004) that demonstrated heterotrophy promoting endosymbiont proliferation and chlorophyll synthesis, although these studies were conducted over longer time scales (3-8 weeks).

Our results suggest that $P$. acuta responds to short periods of extreme low-light levels primarily through adjustments of photophysiological attributes. Previous studies by Muscatine and Cernichiari (1969) and Muscatine et al. (1981) that incubated P. damicornis with ${ }^{14} \mathrm{C}$ in situ for $24 \mathrm{~h}$ reported low contribution of heterotrophy to the daily carbon need of Pocillopora, suggesting that unfed corals were not substantially disadvantaged by being deprived of heterotrophic inputs. Heterotrophy probably plays a more important role in influencing acclimation responses in coral species that depend on heterotrophically acquired carbon to meet their daily metabolic energy requirements (e.g., Porites lobata, Porites compressa, Montipora capitata; Palardy et al. 2008). Further, the effect of feeding is likely only apparent when corals are stressed, i.e., when the endosymbiont density is lower than normal levels (Jones and Yellowlees 1997). In the current study, the mean endosymbiont densities $\left(0.671\right.$ and $0.978 \times 10^{6}$ cells cm $\mathrm{cm}^{-2}$ for 4 and 40 PAR, respectively) were within the range measured in situ previously for $P$. acuta in Singapore $\left(0.5-1 \times 10^{6}\right.$ cells cm$^{-2}$; Browne et al. 2015) and in the Great Barrier Reefs, Australia $\left(0.32-1.01 \times 10^{6}\right.$ cells cm$^{-2}$; Ulstrup et al. 2006). It is possible that longer periods of even lower light may reduce endosymbiont density and lead to increased heterotrophy but, even in Singapore, such conditions are rare. Additional work is required to determine the role of heterotrophy in $P$. acuta during chronic periods (several week to months) of low light.

We identified among-genotype variation for areal chl $a$ concentration [ANOVA, $F(5,64)=4.71, P<0.001]$ and prey clearance rate [ANOVA, $\mathrm{F}(5,32)=8.38, P<0.001$; Fig. 1, Table S2]. Although reaction norms crossed for all measured variables (Fig. 1), these $\mathrm{G} \times \mathrm{E}$ interactions were only significant between genotype and light for cellular chl $a$ concentration [ANOVA, $F(5,64)=4.25, P=0.002$; Fig. 1, Table S2]. Notably, areal chl $a$ concentration and feeding rate in Genotype F were significantly higher than the other genotypes regardless of treatment (Fig. 1, Table S4 and S5). Three fragments (out of 16) from Genotype $\mathrm{F}$ were dead by the end of the experiment, compared to two fragments from Genotype B, and one fragment each from Genotype A, D, and E (Table S1). While there were exceptions (as described above), most of the genotypes displayed similar directions in their responses, indicating photoacclimation in $P$. acuta is broadly predictable.

As development of tropical shorelines accelerates, coral reefs are increasingly threatened by deteriorating water clarity (Heery et al. 2018). Identifying species and genotypes that have an acclimation advantage can help understand and predict the composition of present and future urban reefs. Our study demonstrates that $P$. acuta collected from Singapore can respond rapidly to very low-light conditions by adjusting their photophysiology. It is interesting that, even though P. acuta actively consumed Artemia, endosymbiont density or chl $a$ concentrations did not differ between fed and unfed corals, and there was no significant difference between the feeding rates of corals exposed to the two differing low-light levels. While genotypes varied in the level of plasticity (for heterotrophy and photoacclimation) expressed, there were limited $\mathrm{G} \times \mathrm{E}$ interactions, suggesting that this is likely a typical response of local $P$. acuta genotypes to very low-light conditions. Findings here indicate that $P$. acuta is resilient to acute periods of low-light levels over short time scales (i.e., days), and this may partly explain its persistence on highly sedimented reefs in Singapore. 
Supplementary Information The online version contains supplementary material available at https://doi.org/10.1007/s00227-021-03900-4.

Acknowledgements Many thanks to Jani Tanzil and Ian Chan for their assistance with coral collection, and to Andrew Bauman for his comments on an early draft. We acknowledge the St. John's Island National Marine Laboratory, a National Research Infrastructure under the National Research Foundation Singapore, for providing the facility necessary for conducting the research.

Funding This study was funded by the National Research Foundation, Prime Minister's Office, Singapore under the Marine Science Research and Development Programme (MSRDP-P05).

Data availability The datasets generated during and/or analysed during the current study are available from the corresponding author on reasonable request.

\section{Declarations}

Conflict of interest The authors have no conflicts of interest to declare that are relevant to the content of this article.

Ethical approval All research was carried out with permission of the Singapore National Parks Board (Permit no. NP/RP15-133).

Open Access This article is licensed under a Creative Commons Attribution 4.0 International License, which permits use, sharing, adaptation, distribution and reproduction in any medium or format, as long as you give appropriate credit to the original author(s) and the source, provide a link to the Creative Commons licence, and indicate if changes were made. The images or other third party material in this article are included in the article's Creative Commons licence, unless indicated otherwise in a credit line to the material. If material is not included in the article's Creative Commons licence and your intended use is not permitted by statutory regulation or exceeds the permitted use, you will need to obtain permission directly from the copyright holder. To view a copy of this licence, visit http://creativecommons.org/licenses/by/4.0/.

\section{References}

Anthony KRN (2000) Enhanced particle-feeding capacity of corals on turbid reefs (Great Barrier Reef, Australia). Coral Reefs 19:59-67

Anthony KRN, Fabricius KE (2000) Shifting roles of heterotrophy and autotrophy in coral energetics under varying turbidity. J Exp Mar Biol Ecol 252:221-253

Bessell-Browne P, Negri AP, Fisher R, Clode PL, Jones R (2017) Impacts of light limitation on corals and crustose coralline algae. Sci Rep 7:11553

Bongaerts P, Riginos C, Hay KB, van Oppen MJ, Hoegh-Guldberg O, Dove S (2011) Adaptive divergence in a scleractinian coral: physiological adaptation of Seriatopora hystrix to shallow and deep reef habitats. BMC Evol Biol 11:303

Bradshaw AD (1965) Evolutionary significance of phenotypic plasticity in plants. Adv Genet 13:115-155

Browne NK, Tay JK, Low J, Larson O, Todd PA (2015) Fluctuations in coral health of four common inshore reef corals in response to seasonal and anthropogenic changes in water quality. Mar Environ Res 105:39-52
Chou LM (2006) Marine habitats in one of the world's busiest harbours. In: Wolanksi E (ed) The environment in Asia Pacific harbours. Springer, Dordrecht, pp 377-391

Chow GSE, Chan SYK, Jain SS, Huang D (2019) Light limitation selects for depth generalists in urbanised reef coral communities. Mar Environ Res 147:101-112

Clayton WS, Lasker HR (1982) Effects of light and dark treatments on feeding by the reef coral Pocillopora damicornis (Linnaeus). J Exp Mar Biol Ecol 63:269-279

Dustan P (1982) Depth-dependent photoadaption by zooxanthellae of the reef coral Montastrea annularis. Mar Biol 68:253-264

Falkowski PG, Dubinsky Z (1981) Light-shade adaptation of Stylophora pistillata, a hermatypic coral from the Gulf of Eilat. Nature 289:172-174

Ferrier-Pagès C, Witting J, Tambutté E, Sebens KP (2003) Effect of natural zooplankton feeding on the tissue and skeletal growth of the scleractinian coral Stylophora pistillata. Coral Reefs 22:229-240

Foster AB (1979) Phenotypic plasticity in the reef corals Montastrea annularis and Siderastrea siderea. J Exp Mar Biol Ecol 39:25-54

Heery EC, Hoeksema BW, Browne NK, Reimer JD, Ang PO, Huang D, Friess DA, Chou LM, Loke LHL, Saksena-Taylor P, Alsagoff N, Yeemin T, Sutthacheep M, Vo ST, Bos AR, Gumanao GS, Hussein MAS, Waheed Z, Lane DJW, Johan O, Kunzmann A, Jompa J, Suharsono TD, Bauman AG, Todd PA (2018) Urban coral reefs: degradation and resilience of hard coral assemblages in coastal cities of East and Southeast Asia. Mar Pollut Bull 135:654-681

Hoegh-Guldberg O, Smith GJ (1989) The effects of sudden changes in light, temperature and salinity on the population density and export of zooxanthellae from the reef corals Seriatopora hysterix and Styllophora pistillata. Mar Ecol Prog Ser 129:279-303

Houlbrèque F, Ferrier-Pagès C (2009) Heterotrophy in tropical scleractinian corals. Biol Rev 84:1-17

Houlbrèque F, Tambutté E, Allemand D, Ferrier-Pagès C (2004) Interactions between zooplankton feeding, photosynthesis and skeletal growth in the scleractinian coral Stylophora pistillata. J Exp Biol 207:1461-1469

Iglesias-Prieto R, Beltran VH, Lajeunesse TC, Reyes-Bonilla H, Thome PE (2004) Different algal symbionts explain the vertical distribution of dominant reef corals in the eastern Pacific. Proc R Soc Lond B Biol Sci 271:1757-1763

Jeffrey SW, Humphrey GF (1975) New spectrophotometric equations for determining chlorophylls $a, b, c 1$ and $c 2$ in higher plants, algae and natural phytoplankton. Biochemie Und Physiolie Der Pflanzen 167:191-194

Johannes RE, Wiebe WJ (1970) Method for determination of coral tissue biomass and composition. Limnol Oceanogr 15:822-824

Jones RJ, Yellowlees D (1997) Regulation and control of intracellular algae (= zooxanthellae) in hard corals. Phil Trans R Soc Lond B Biol Sci 352:457-468

Jones R, Fisher R, Stark C, Ridd P (2015) Temporal patterns in seawater quality from dredging in tropical environments. PLoS ONE 10:e0137112

Kleypas JA, McManus JW, Menez LA (1999) Environmental limits to coral reef development: where do we draw the line? Am Zool 39:146-159

Lavorano S, Gili C, Muti C, Taruffi M, Corsino D, Gnone G (2008) The CORALZOO project-preliminary results of the evaluation of different types and concentrations of zooplankton food on the growth of Pocillopora damicornis (Linnaeus, 1758) comparing diurnal and nocturnal feeding. In: Leewis RJ, Janse M (eds) Advances in coral husbandry in public aquariums. Burgers' Zoo, Arnhem, pp 19-25

Lewis JB (1976) Experimental tests of suspension feeding in Atlantic reef corals. Mar Biol 36:147-150 
McCloskey LR, Muscatine L (1984) Production and respiration in the Red Sea coral Stylophora pistillata as a function of depth. Proc R Soc Lond B Biol Sci 222:215-230

Muscatine L, Cernichiari E (1969) Assimilation of photosynthetic products of zooxanthellae by a reef coral. Biol Bull 137:506-523

Muscatine L, McCloskey LR, Marian RE, R, (1981) Estimating the daily contribution of carbon from zooxanthellae to coral animal respiration. Limnol Oceanogr 26:601-611

Ng CS, Lim JX, Sam SQ, Kikuzawa YP, Toh TC, Wee TW, Sim WT, Ng NK, Huang D, Chou LM (2019) Variability in skeletal bulk densities of common hard corals in Southeast Asia. Coral Reefs 38:1133-1143

Palardy JE, Grottoli AG, Matthews KA (2006) Effect of naturally changing zooplankton concentrations on feeding rates of two coral species in the Eastern Pacific. J Exp Mar Biol Ecol 331:99-107

Palardy JE, Rodrigues LJ, Grottoli AG (2008) The importance of zooplankton to the daily metabolic carbon requirements of healthy and bleached corals at two depths. J Exp Mar Biol Ecol 367:180-188

Pang HE, Poquita-Du RC, Jain SS, Huang D, Todd PA (2021) Amonggenotype responses of the coral Pocillopora acuta to emersion: implications for the ecological engineering of artificial coastal defences. Mar Environ Res. https://doi.org/10.1016/j.marenvres. 2021.105312

Pigliucci M (2005) Evolution of phenotypic plasticity: where are we now? Trends Ecol Evol 20:481-486

Poquita-Du RC, Huang D, Chou LM, Mrinalini, Todd PA (2019a) Short term exposure to heat and sediment triggers changes in coral gene expression and photo-physiological performance. Front Mar Sci 6:121

Poquita-Du RC, Quek ZB, Jain SS, Schmidt-Roach S, Tun K, Heery EC, Chou LM, Todd PA, Huang D (2019b) Last species standing: loss of Pocilloporidae corals associated with coastal urbanization in a tropical city state. Mar Biodivers 49:1727-1741

R Core Team (2019) R: a language and environment for statistical computing. R Foundation for Statistical Computing, Vienna, Austria. R version 3.6.2. https://www.R-project.org/. Accessed 14 June 2019

Roth MS (2014) The engine of the reef: photobiology of the coral-algal symbiosis. Front Microbiol 5:422

Schlichting CD (1989) Phenotypic plasticity in Phlox II. Plasticity of character correlations. Oecologia 78:496-501

Schlichting CD, Pigliucci M (1998) Phenotypic evolution: a reaction norm perspective. Sinauer

Séré MG, Massé LM, Perissinotto R, Schleyer MH (2010) Influence of heterotrophic feeding on the sexual reproduction of Pocillopora verrucosa in aquaria. J Exp Mar Biol Ecol 395:63-71
Stearns SC (1989) The evolutionary significance of phenotypic plasticity. Bioscience 39:436-446

Stearns SC (1992) The evolution of life histories. Oxford University, Oxford

Stimson J, Kinzie RA III (1991) The temporal pattern and rate of release of zooxanthellae from the reef coral Pocillopora damicornis (Linnaeus) under nitrogen-enrichment and control conditions. J Exp Mar Biol Ecol 153:63-74

Thimijan RW, Heins RD (1983) Photometric, radiometric, and quantum light units of measure: a review of procedures for interconversion. HortScience 18:818-822

Titlyanov EA, Titlyanova TV (2002) Reef-building corals—symbiotic autotrophic organisms: 2. Pathways and mechanisms of adaptation to light. Russ J Mar Biol 28:S16-S31

Titlyanov E, Bil K, Fomina I, Titlyanova T, Leletkin V, Eden N, Malkin A, Dubinsky Z (2000) Effects of dissolved ammonium addition and host feeding with Artemia salina on photoacclimation of the hermatypic coral Stylophora pistillata. Mar Biol 137:463-472

Titlyanov EA, Titlyanova TV, Yamazato K, van Woesik R (2001a) Photo-acclimation dynamics of the coral Stylophora pistillata to low and extremely low light. J Exp Mar Biol Ecol 263:211-225

Titlyanov EA, Titlyanova TV, Yamazato K, van Woesik R (2001b) Photo-acclimation of the hermatypic coral Stylophora pistillata while subjected to either starvation or food provisioning. J Exp Mar Biol Ecol 257:163-181

Todd PA (2008) Morphological plasticity in scleractinian corals. Biol Rev 83:315-337

Todd PA, Ladle RJ, Lewin-Koh NJ, Chou LM (2004) Genotype $\times$ environment interactions in transplanted clones of the massive corals Favia speciosa and Diploastrea heliopora. Mar Ecol Prog Ser 271:167-182

Todd PA, Ong X, Chou LM (2010) Impacts of pollution on marine life in Southeast Asia. Biodiv and Conserv 19:1063-1082

Ulstrup KE, Berkelmans R, Ralph PJ, Van Oppen MJ (2006) Variation in bleaching sensitivity of two coral species across a latitudinal gradient on the Great Barrier Reef: the role of zooxanthellae. Mar Ecol Prog Ser 314:135-148

Yonge CM, Nicholls AG (1931) Studies on the physiology of corals: $\mathrm{V}$. The effects of starvation in light and in darkness on the relationship between corals and zooxanthellae. Sci Rep Great Barrier Reef Exped 1:177-211

Publisher's Note Springer Nature remains neutral with regard to jurisdictional claims in published maps and institutional affiliations. 